\title{
THE BALINESE TRADITIONAL CULINAIR MUST BE SURVIVED AS A GREEN TOURISM TO PRESERVE SUSTAINABLE TOURISM
}

\author{
I Made Sudiarta. Polytechnic State of Bali \\ sudiartamade@yahoo.co.id
}

\begin{abstract}
According to an International Magazine stated that Bali is the best of the world destination country, not famous only of the splendor of Bali and its unique culture, but also its culinair. (Bali Post, Nov 2015).

Bali which is said to be the island of one thousand temples: Bali is the island of GODS; Bali is a paradise; also famous with various kinds of specific and typical traditional culinairs. (Sulistiyo, 2011, 94).

This Balinese traditional culinair must be surfived as a green tourism to preserve sustainable tourism, to be able to be enjoyed by young generations (Picard, 1996, 64).

This decision was committed during the audiency of Bali Post Newspaper Commity to PT. Sinar Sosro, the sales office of Bali \& NUSRA Region, last Friday june 10 $0^{\text {th }}, 2016$ just a few days ago. (Bali Post, June 2016).

It is expected that by the frequently of culinair festival we can preserve sustainable tourism, and finally the Balinese Traditional Culinair could be surfived as a green tourism. (Bungin, 2007:87).
\end{abstract}

Keywords : Balinese, Traditional Culinair, Surfive, Green Tourism, Sustainable Tourism.

\section{INTRODUCTION}

The life style of men on all over the world are always developing every day and every time. Nowadays the income percapita of state workers are more than enough. The prosperous of each family is getting better. In order to prevent bored feeling after working 5 days full, most people go travelling to a resort, to visit tourism attraction, and to have lunch or dinner in outdoor, especially at the tourist attraction place. (Mulyono, 2010:57).

Most visitors feel bored to enjoy regular food. They want to taste such a different food, specific cuisine, typical region to experience a new life style. (O'Connor, 2000:143).

In order to fulfill the intention of the visitors, local visitor or foreigner ones, The Balinese Traditional Culinair is so sufficient to be offered. (Mills, Robert, 2000:67).

The most famous of Balinese Traditional Culinair is SUCLING PIG ( $B a b i$ Guling). The taste of this sucling pig is so delisious, mild, and it is completed by various of fried meat, Sambal Matah, Sambal Terasi, Sambal Uleg with Lemo, Sambal Goreng with Chili. (Bungin, 2007:86). 
A sales promotion manager of PT. Sinar Sosro, the office sale of Bali \& NUSRA, namely Miss Ni Wayan Rusmini, said that she often joins in every event in the island of God, Bali.

This participation is to prove that PT. Sostro is highly support the surfival of Balinese tourism, especially The Traditional Culinair. (Bali Post, June 2016).

Further, Miss Ni Wayan Rusmini said that the existence of Balinese Traditional Culinair is always developed every day and every time. In order to serve a six million visitors who will come to Indonesia in this year 2016. (Bali Post, June 2016).

This statement is proved by the fact that over than half million enterpreneurs choosed to run a Balinese Traditional Culinair business.

In order to keep the Balinese Traditional Culinair always exist and highly developed, it should be competited frequently.

On that good opportunity, PT. Sinar Sosro, the sales office of Bali \& NUSRA region was highly to support and to commit the Balinese Traditional Culinair competition which will be held by Bali Post Newspaper Commity would be successfully.

The incoming event namely Food Truck Festival 2016 will be highly prestige, especially for the Balinese Traditional Culinair business.

The PT. Sinar Sosro, the sales office of Bali \& NUSRA, decided to support $100 \%$ of Food Truck Festival 2016 which want to developing the Balinese Traditional Culinair Business in the future, in Bali, especially in Denpasar. (bali post, June 2016).

\section{The Balinese Traditional Culinair has a good prospect}

According to government rules and regulation No. 10, in the year 2009, chapter VI, item 14, it was stated as follows : (Mastiani, 2016:74).

Tourism business includes such as follows : tourism attractions, tourism resort, tour guiding, food and beverage service, tourism event, tourist objects, conference, etc.

If we search, we will see some tourism components such as : tourist attraction, food and beverage services, accommodation, recreation and MICE, could highly support the Balinese Traditional Culinair business. (Mastiani, 2016:73).

The Balinese Traditional Culinair is said to be an attraction, because the culinair itself, beside as a basic need, but also as to fulfill the personal ego of customer who has passed over their basic need. (Mastiani, 2016:74).

To taste a certain culinair from a different country brings a certain satisfaction to himself after tasting a certain culinair, because it gives a special different taste to the taster himself. (Erawan, 2008:62).

The Balinese Traditional Culinair is so sufficient to be developed here in Bali as a creative industry, meanwhile bali is said to be the premier tourism destination country in Indonesia, which has variously of cultures, including their local Balinese Traditional Culinair. (Mastiani, 2016:74).

As we know that, every region in Indonesia, especially in Bali, has their specific menu and specific term of culinair which are so sufficient to be promoted in tourism industry. (Harris, 2002:48). 
Especially for foreigner who has enjoyed the Balinese Traditional Culinair would feel themselves experiencing a memorable experience and memorable activity. (Moscardo, 2003:103).

Like for most Asian, rice is the steple food of the Balinese. However, Balinese food forms a distinct cuisine and many dishes have great ritual significance. (Jan Hendrik and Wisnu Wardana, 2013:49).

Babi Guling (Spit-roasted suckling pig) as the signature Balinese dish, an essential component of any Balinese ceremonial occasion. (Mill, 2000:122).

The preparation of most Balinese dishes is labour intensive and time consuming, often requiring a lot of cooks and assistants working from dusk to dawn. Cooking food for the banquet that accompanies many ceremonial occasion is an important form of socialization, with community members from all clans and generations sharing the work-load. (Mulyono, Mauled, 2010:133).

With the rise of both urbanization and tourism, Balinese Traditional Cuisine like Babi Guling is no longer served just for special occasions. Balinese Traditional Cuisine is available at roadside food stalls, while many hotels and restaurants serve Balinese food, albeit with the spiciness toned down to suit a westerner's tender plate. However, as Balinese Traditional Cuisine becomes a profession, the knowledge of cooking The Balinese Traditional dishes among the general population is being lost. (Jan Hendrik, 2013:143).

\section{RESEARCH METHODOLOGY}

The research which is used in this paper is tourism Sociology. By using the tourism sociology research, is expecting to find the fenomenon of research objects.

Besides using tourism sociology technique, I am as a researcher also using kwalitative data which comes from premier data and secondair ones.

Most data are got from observation, depth interview, and documentations. Data are got from those Balinese Traditional Culinair staffs, the business owner, the seller of Balinesse traditional culinair.

The method of this research is used purposive, which means to choose the informants who knows and understands well about the Balinese Traditional Culinair well enough. (Ridwan, 2007:93).

Analyze of this research is using descriptive kwalitative which means by explaining in detail about all data which have been got from all respondents. After that, all data are transformed, analyzed well, and finally to be exposed widely to the public.

\section{RESULT AND DISSCUSSION}

\section{The Balinese Traditional Culinair must be survived.}

Bali as the best world tourism destination, besides having many beautiful beaches, panoramas, the splendor of its cultures, Bali also famous with its Balinese Traditional Culinairs.

The Balinese Traditional Culinairs are so specific and so specialty and many varieties of cuisines.

The existence of Balinese Traditional Culinair must be survived at all the time, so that, it could be enjoyed by young generation in the future and forever. 


\section{A GOOD PROSPECT OF BALINESE TRADITIONAL CULINAIR}

Culinair (food and beverage service) was stated briefly on tourism business, especially stated on government rules and regulations number 10 , in the year 2009, chapter VI, item 14. (Mastiani, 2016:73).

It was stated there clarly enough about tourism business such as follows : tourist attractions, tourism areas, tourism transportation, tour services, tourism recreations, meeting incentive, conference and exhibition (MICE), tourism informations, water recreations, and spa. (Mastiani, 2016:74).

If we search in detail about part of tourism business, we noticed that many departments could support the existence of Balinese Traditional Culinair, such as : tourist attractions on all over Bali, food and beverages, accomodations, entertainment and recreations, and MICE.

All those departments above should support the existence of Balinese Traditional Culinair, in order this such culinair could be enjoyed and tasted by young generation in the future, and always exist forever.

\section{COOKING CLASS}

In order to get a complete knowledge about the Balinese Traditional Culinair, especially for those overseas visitors who wants to know much about Balinese Traditional Culinair, it is advisable to attend a cooking class.

There are many travel agents lets visitors to attend the cooking class such as Rural Class which is done by Tour East (travel agent) where the location of cooking class was in Gulingan Village in Mengwi Regency, at the edge of beautiful scenery rice field with its tropical fruit trees.

In that activity, the visitors are actively preparing a various Bali local spices, joining the cooking process directly in traditional kitchen, then tasted the cuisine which they cooked together as their light lunch.

Another example is, the cooking class which is applied by Vivai Cooking School, completed with menu and itinerary.

The Vivai cooking class are divided into two sections i.e : sea-food cooking class, and Balinese Traditional Food Cooking Class. (Mastiani, 2016:74). In the Vibai cooking class, especially for the attendant of Balinese Traditional Cooking Class, the student should go to a traditional market near the school to buy various spices that are needed for cooking the Balinese food, mixing the spices into Bumbu Bali, cooks the Balinese food which is guides by some expert tour guides, until the food are ready, then eaten that Balinese food by the visitors themselves as their light lunch.

\section{CONCLUSSION}

After axplaining much about the Balinese Traditional Culinair, starting from the history. The motivation to make The Balinese Traditional Culinair to be survived as a green tourism, in order to preserve sustainable tourism, etc. in this good opportunity I am as researcher would like to offer a small conclusion.

Firstly, The Balinese Traditional Culinair must be survived as a green tourism to preserve sustainable tourism in Indonesia, especially in Bali.

Bali which was tempted as the best world tourism destination country, should have a trade mark, as an icon of Bali's specific and specialty food to be 
offered to six million visitors who will come to Bali visiting the uniqueness of Bali.

Bali could be famous on all over the world, not just only by its beautifull beaches, the splendor of Bali and beyond, its culture, but the most important thing is the Balinese Traditional Culinairs.

How to preserve the sustainable tourism in Bali ?, is by sharing the knowledge of the secret Balinese spices for processing Balinese Traditional Culinair to the young generation and especially to the foreign visitors.

How to share the knowledge which is meant above ?, is by allowing to foreigner visitors to attend and practicing directly how to cook Balinese Traditional Cuisine at rural class which is done by Tour East travel agent, and the cooking class which is done by Vivai Cooking School.

\section{SUGGESTIONS}

There is no ivory without cracking, that is a regular proverb which was spreading in all over Indonesian archipelago, especially in Melayu territory. Although the Indonesian government has done his best in promoting The Balinese Traditional Culinair to be survived as a green tourism in order to preserve sustainable tourism, but still there are some suggestions to be offered in this good opportunity such as follows :

- In order to preserve sustainable tourism especially in Bali, more food festivals should be done in Bali Tourism Development which are spread out in all over Bali, such as in Sanur, Kuta, Nusa Dua, Jimbaran, Ubud, Bali Art Festival, in an International hotel and in the Villages.

- The Balinese Traditional Culinair must be always survived as a green tourism by persuading the foreign visitors to join the cooking class which is done by Tour East travel agent, to give them a good opportunity to cook The Balinese Traditional Culinair by themselves, not just gave them a kind of theory only, but to buy the local spices in near the school, then mixing the spices to be Bumbu Bali, cooking the food by visitors themselves, and finally tasted The Balinese food which has been cooked together as their light lunch.

- By doing this activity, $\mathrm{i}$ believe that most visitors felt a memorable and an unforgettable experience they had before living Bali, the best world destination country. 


\section{REFERENCES}

Bali Post, Nov 2015 and 2016, Denpasar, Bali.

Bungin, Burhan (2007) Prinsip-prinsip dan Kriteria Ekowisata untuk Bali. (Hasil Lokakarya Pelatihan Ekowisata se-Bali di Sanur).

Erawan, I Nyoman (2008), Manajemen Pembangunan Pariwisata Berkelanjutan, Program Magister, Kajian Pariwisata (hand out) Universitas Udayana, Denpasar, Bali.

Harris, Rob et al (2002), Sustainable Tourism A Global Perspective, Oxford: Elsevier Ltd.

Jan Hendrik and Wisnu Wardana, Tri Hita Karana, 2013, printed by Gramedia, Jakarta.

Mastiani, Media Bina Ilmiah, 2016, Vol. 10 No. 3.

Mill, Robert C, 2000, Tourism The international Business (Edisi Bahasa Indonesia), Jakarta, PT. Raja Grafisindo Persada.

Moscardo, Gianna (2003), Interpretation and Sustainable Tourism : Function, Examples and Principles, (Journal of Tourism Studies, Vol 14, No. 1, May 2003.

Mulyono, Mauled, 2010, Menggerakkan Ekonomi Kreatif, Antara Tuntutan dan Kebutuhan, Jakarta, Raja Grafisindo Persada.

O'Connor, Justin, 2000, The Devinition of The Cultural Industries, Queensland University of Technology, The Europe Jornal of Arts Education, Vol. 2, No. 3, February 2000, PP. 15-27 Oct.

Picard, Michel, 1996, Bali Cultural Tourism and Touristic Culture, Singapore Archipelago Press.

Sulistiyo, yodo dan Handayani Yuanita, 2012, Pemanfaatan Kreatifitas dan Inovasi Dalam Meningkatkan Competitiveness Indonesia Melalui Industri Kreatif, DalamStrategic Management, Jakarta : The Ary Suta Centre. 